\title{
La boîte de Pandore
}

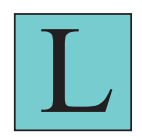

es orthodontistes aiment les visages. Ils s'attardent sur la courbure des lèvres, la saillie du menton, l'harmonie des volumes et de la lumière. Ils les photographient, les dessinent, pour mieux les comprendre.

$\mathrm{Au}$ milieu de ces visages si différents, de tout âge et de tout caractère, je garde en mémoire, comme une image rémanente, les traits d'un patient qui ne ressemblait à aucun autre.

Sa démarche lente, son regard las, caché sous des paupières grises et plissées ; l'esquisse même d'un sourire lui demandait un effort. L'évocation de sa malocclusion, des désordres parodontaux et dentaires ne semblait susciter que peu d'intérêt chez cet homme, qui haussait des épaules, comme résigné. C'était un patient qui dormait peu, et très mal. Le diagnostic d'apnées obstructives sévères venait d'être posé, et il était adressé pour bilan dentaire avant la pose d'orthèse.

La consultation se termine, alors que je retiens les milliers de questions qui tambourinent dans mon crâne. Quelle différence avec ces hommes et ces femmes, qui frappent à la porte du cabinet pour une cure de jouvence, et signent un pacte avec le diable (la contention) pour la jeunesse éternelle !

Nous nous revoyons à quelques mois de là. J'ai eu le temps de nourrir mes interrogations par de bonnes lectures sur les troubles du sommeil, prête à orienter mon examen... et je trouve un homme transformé.

Le même décalage sagittal, oui, mais le visage animé d'expressions, le regard alerte, et une réelle motivation au changement.

- Je dors enfin. Mon sommeil est devenu réparateur. L'orthèse a changé ma vie. La polysomnographie montre que j'arrive à atteindre les phases de sommeil paradoxal! Vous rendez-vous compte que pendant toutes ces années, je n'ai jamais eu le souvenir d'un rêve?

- Quel changement, en effet. Heureusement que le diagnostic d'apnées du sommeil a été posé. Vous auriez pu continuer à vivre épuisé pendant longtemps. Votre indice de somnolence* est devenu normal... c'est impressionnant.

- Il y a quand même quelque chose dont les apnées me protégeaient.

Je suis interloquée. Cet homme n'était que l'ombre de lui-même, luttant contre le sommeil pour chaque geste. Que regretter de cette vie ? Il sourit (il sourit !) et ajoute :

- Quand je ne faisais pas de rêves... je ne faisais pas de cauchemars.

Julia COHEN-LEVY

* L'indice d'Epworth. 


\section{Pandora's Box}

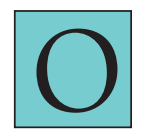

rthodontists like faces. They lovingly ponder the curvature of lips, the thrust of chins, the harmony of their structures reflected in light. They photograph faces and sketch them in an attempt to understand them better. From a vast gallery of widely varying images of every age and every type, my mind's eye focuses on one well-remembered picture, of the facial traits of a patient who was like no other. I vividly recall his slow gait, his weary stare, masked by drooping, deeply lined gray eyelids. For him squeezing out even the hint of a smile was a painful effort. Evocation of his malocclusion and his dental and periodontal problems didn't seem to interest him at all. He just shrugged his shoulders in silent resignation.

A patient who slept little and very badly, he had just been diagnosed with a severe case of sleep apnea. He had come to me for a dental evaluation before he began to wear an orthosis.

When the consultation was over a thousand questions beat a tattoo in my head. What a difference, I thought, between most men and the women, who entered my waiting room hoping to find the Fountain of Youth and ready to sign a pact with the devil (in the form of permanent retention) if that would promise them eternal youth!

This patient and I saw each other again a few months later. I had partially quenched my thirst for knowledge about his problem by boning up on disturbances of sleep, preparing myself to re-examine him....and when I did I found him transformed.

He still had his protrusion, yes, but his face glowed with animated expression, his regard was alert, radiating motivation to seek new pathways.

- I'm finally sleeping, he said, and sleep has become a restorative for me. The orthosis has changed my life. The polysomnograph showed that I had reached the stage of paradoxical sleep! Can you believe it; in all those years I can never once remember dreaming?

- What a change, I said. I'm so happy that they were able to make a diagnosis of sleep apnea. You would have gone on living in a state of exhaustion. Now your sleep index* is normal... that's very impressive.

- There is, he said, just one little thing that sleep apnea was good for.

I was flabbergasted. This man had been the shadow of his true self, fighting against drowsiness with every move that he made. What possible regrets could he now have for his past life? He smiled (and what a smile it was!) and added:

- When I didn't dream... I didn't have nightmares either.

Julia COHEN-LEVY

\footnotetext{
* The Epworth index.
} 